\title{
Ayak kaynamamaları
}

\section{Non-unions of the foot}

\author{
Emre Baca
}

T.C. S.B.Ü. Bakırköy Dr. Sadi Konuk Eğitim ve Araştırma Hastanesi, İstanbul

\begin{abstract}
Komplikasyonlar ile ilgili endişe, sağlık hizmeti sunucularının önemli bir oranda zamanını tüketebilir. Cerrahi disiplinlerde, görünüşte küçük olan komplikasyonlar, hem pratisyen hekimler hem de hastalar için büyük hayal kırıklığı ve endişe uyandırır. Cerrahi teknolojileri ve teknikleri geliştirmedeki ana hedef, hasta bakımı kalitesini arttırmak ve komplikasyonları azaltmaktır. Cerrahi komplikasyonların başarılı bir şekilde idare edilmesi, söz konusu patolojinin tam olarak anlaşılması ve hasta güvenini sağlamaya yönelik etkili bir tedavi sunma kabiliyeti gerektirir. Kaynamama, iki karşıt kemik yüzey arasında iyileşmenin olmadığı karışık bir cerrahi komplikasyondur. Alt ekstremitedeki çeşitli anatomik bölgelerde kaynamama eğilimlerinin nispeten yüksek olduğu tespit edilmiştir. Tibia şaft kırıklarının kaynamaması olguların \%10-60'ında ortaya çıkabilir. Ardayak ve ayak bileği artrodezleri sonrasında \%10'a varan kaynamamalar bildirilmiştir; bu oran, üçlü artrodezlerde \%6-33 arasında değişmektedir. Birinci metatarsofalangeal eklem (MTF) ve birinci tarsometatarsal eklem (TMT) artrodezlerinin kaynamama oranları ise \%10'un altındadır. Ayak ve ayak bileğinde cerrahi kaynamama nadir değildir. Bu nedenle cerrahların, özellikle de kaynamama eğilimi olan durumlarda, nispeten yüksek bir şüphe endeksi olmalıdır.
\end{abstract}

Anahtar sözcükler: ayak; kaynamama
Concerns about complications can consume a significant time of the health care providers. In surgical disciplines, seemingly minor complications are a major frustration and concern for both general practitioners and patients. The main goal in developing surgical technologies and techniques is to improve patient care quality, and reduce complications. Successful management of surgical complications requires a thorough understanding of the pathology, and the ability to provide effective treatment to maintain patient confidence. Non-union is a complicated surgical complication in which there is no healing between the two opposing bone surfaces. In various anatomic regions of the lower extremity it has been found that the tendency to nonunion is relatively high. Non-union of tibial shaft fractures may occur in $10-60 \%$ of cases. Up to $10 \%$ non-unions have been reported after hindfoot arthrodesis and ankle arthrodesis; this ratio varies between $6-33 \%$ in triple arthrodesis. Arthrodeses of the first metatarsophalangeal joint (MTF) and the first tarsometatarsal joint (TMT) are less than $10 \%$ of the incidences of arthrodesis. Surgical non-union is not uncommon in the foot and ankle. For this reason, surgeons should have a relatively high level of suspicion, particularly in situations that tend to have predisposition to non-union.

Key words: foot; non-union
K omplikasyonlar ile ilgili endişe, sağlık hizmeti sunucularının önemli bir oranda zamanını tüketebilir. Cerrahi disiplinlerde, görünüşte küçük olan komplikasyonlar hem pratisyen hekimler hem de hastalar için büyük hayal kırıklığı ve endişe uyandırır. Cerrahi teknolojileri ve teknikleri geliştirmedeki ana hedef hasta bakımı kalitesini arttırmak ve komplikasyonları azaltmaktır. Cerrahi komplikasyonların başarılı bir şekilde idare edilmesi söz konusu patolojinin tam olarak anlaşılması ve hasta güvenini sağlamaya yönelik etkili bir tedavi sunma kabiliyeti gerektirir. Kaynamama, iki karşıt kemik yüzey arasında iyileşmenin olmadığı karışık bir cerrahi komplikasyondur. Alt ekstremitedeki çeşitli anatomik bölgelerde kaynamama eğilimlerinin nispeten yüksek olduğu tespit edilmiştir. Tibia şaft kırıklarının kaynamaması olguların \%10-60'ında ortaya çıkabilir. ${ }^{[1-4]}$ Ardayak ve ayak bileği artrodezleri sonrasında \%10 a varan kaynamamalar bildirilmiştir; bu oran üçlü artrodezlerde \%6-33 arasında değişmektedir. ${ }^{[5-8]}$ Birinci metatarsofalangeal eklem (MTF) ve birinci tarsometatarsal eklem (TMT) artrodezlerinin kaynamama oranları ise \%10'un altındadır. ${ }^{[9-14]}$ Ayak ve ayak bileğinde cerrahi kaynamama nadir değildir. Bu nedenle cerrahların, özellikle de kaynamama eğilimi olan durumlarda, nispeten yüksek bir şüphe endeksi olmalıdır.

- İletişim adresi: Op. Dr. Emre Baca, Dr. Tevfik Sağlam Cad. No: 11, Zuhuratbaba, Bakırköy, İstanbul 


\section{KAYNAMAMA TEDAVI STRATEJILERi}

Tedavi stratejileri, kaynamamayı iyileştirmeye odaklanmalıdır. Bununla birlikte, ayak ve ayak bileği kaynamamaları sıklıkla malunion ve deformitelerle ilişkilidir. Buna ek olarak, özellikle de uzun süredir kaynamayan olgularda, kompansasyon nedeniyle yakın mesafedeki eklemlerde sertlik, dizilim bozukluğu ve ağrı olabilir. Bu nedenle, ayağın tamamını, ayak bileğini ve tüm bacağı kapsayan bir yaklaşım benimsenmelidir. Nihai hedef, iyi dizilimde, ağrısız ve fonksiyonel ayak ve ayak bileği sağlamaktır. Bu amaca ulaşmak zor olabilir ve her hastada da mümkün olmayabilir. Bununla birlikte, ağrıda bir miktar rahatlama ve işlevlerde düzelme beklenmelidir. Hastalar, tedavinin süreci uzun ve yavaş olacağını ve sıklıkla çoklu cerrahiler gerektireceğini bilmelidir.

Hastanın hedefleri tipik olarak ağrını kesilmesi ve normal bir işlevdir. Cerrahın başlıca hedefleri kaynama, normal mimari/dizilim, semptomların düzeltilmesi ve işlevselliktir. Hedefler gerçekçi ve ulaşılabilir tutulmalıdır. Tıbbi geçmiş, önceki cerrahi, anatomik bölge, uyumluluk vb. hastanın prognozunu doğrudan etkiler. Cerrah ve hasta, kabul edilebilir sonuç üzerinde ortak bir fikir sahibi olmalıdır. Hastanın motivasyonu, sakatlı̆̆ı, sosyal sorunlar, dava konuları, zihinsel durum ve beklentileri bir revizyon yapılmadan önce göz önüne alınmalıdır.

Kaymama için yapılan revizyon cerrahisi, genellikle kapsamlı planlama, hasta eğitimi, hasta optimizasyonu, uygun teknoloji ve kaynaklar, uzatılmış iyileşme, ileri görüntüleme, ileri cerrahi ve uzun vadeli takibi içerir. Bu hastalar ve aileleri, kaynamamanın iyileşme süreciyle ile ilgili belirsizlikleri, tedavi süresinin uzunluğunu ve çoklu cerrahi müdahalelerin gerekli olabileceğini anlamalıdır.

Ameliyat öncesinde diğer uzmanlık dallarıyla konsültasyon önemlidir. Cerrahi müdahale öncesinde tedavi sonuçlarını olumsuz etkileyebilecek herhangi bir sorun, konunun uzmanı tarafindan ele alınmalıdır.

Ameliyat öncesi noninvaziv alt ekstremite arteriyel incelemelerinde zayıf perfüzyon mevcutsa, damar cerrahisi konsültasyonu tavsiye edilir. Bu incelemeler, önerilen ameliyat ile iyileşme olmayacağını gösterebilir. Arteriyel perfüzyonu arttırmak için vasküler müdahale uygulanabilir veya hastanın cerrahiye uygun bir aday olmadığı söylenebilir.

Dizilimin tekrar sağlanmasında sonra, yara yerinde açılma veya yumuşak doku defisitleri oluşturabilecek şekilde bir insizyon gerekiyorsa, plastik cerrahi konsültasyonu önerilir. Bir plastik cerrah, insizyon için en uygun yeri önerebilir veya kaynamama düzeltmesi sırasında eşzamanlı olarak yumuşak doku rekonstrüksiyonu yapabilir.
Ne yazık ki, uzun süre kaynamayan hastalar oral narkotik ilaçlara bağımlı hale gelebilir. Ağrı kliniğine sevk, hem tedavi sürecinde hem de hastanın detoksifikasyonu ve tüm uyuşturucu ilaçların kesilmesi için yararlıdır. ${ }^{[15-17]}$

Ameliyat öncesi fizik tedavi konsültasyonu almak özellikle erken yük vermeye bağlı kaynamama olan durumlarda önemlidir. Bir fizyoterapist tarafindan yürüyüş, ameliyat sonrası aktivite beklentileri ve yardımcı veya adaptif cihaz kullanımına yönelik eğitim verilebilir. Ayrıca, böyle bir eğitim, hastanın cerrahi sonrasında kendisiyle çalışacak bir fizik tedavi uzmanıyla ilişki geliştirmesi için bir firsattır. Ameliyattan sonra bağımSız ambulasyon için rehabilitasyon gerekli olacaktır. Eninde sonunda çevre eklemlerin gücünü ve hareket açıkığını sağlamak için fizik tedavi gerekecektir.

Yetersiz beslenen veya obez hastalar için bir beslenme uzmanı danışma düşünülmelidir. Açıkça gösterilmiştir ki proteinlerin, özellikle de albümin ve vitaminlerin yetersiz alımı gecikmiş kaynama veya kaynamama ile ilişkilidir. Dahası, obez hastanın kilo vermesine bir beslenme uzmanı ciddi bir şekilde yardımcı olabilir. Obezite teknik olarak cerrahi alanın yükten kurtarılmasını zorlaştırır. ${ }^{[18-21]}$

Endokrinoloji konsültasyonları, özellikle yüksek HgA1 c seviyeleri olan, diyabetik hastalar için yararlıdır. Hoogwerf ve ark. diabetes mellituslu hastalarda komplikasyon insidansı ile yüksek $\mathrm{HgA1}$ c serum düzeyleri arasında doğrusal bir ilişki göstermiştir. ${ }^{[22]}$

$\mathrm{Bu}$ nedenle diabetes mellitus varlığında sıkı glikoz kontrolü, hasta optimizasyonunun bir parçası olmalıdır. Ayrıca, Brinker ve ark. kaynamamanın tespit yetersizliği ve enfeksiyon gibi teknik bir nedenden kaynaklanmadığı durumlarda, güçlü bir şekilde endokrinoloji konsültasyonu önermişlerdir. ${ }^{[23]}$ Endokrinoloji, kaynamamaya neden olan metabolik bozukluğu tespit edebilir ve hastayı optimize etmek için anormalliği tedavi edebilir. Bu tedaviler, düşük $D$ vitamini ve tiroid hormonu düzeylerinin yükseltilmesi ve kan şekeri optimizasyonunu içerir.

Kronik hastalılarda depresyon nadir değildir. Kaynamama hastaları, sıklıkla klinik depresyon belirtileri gösterebilir. Psikiyatri konsültasyonu yararlı olabilir. ${ }^{[24-27]}$

Kaynamama revizyon prosedürlerinin çoğunluğu tek seans ile çözülebilse de; birden çok cerrahi basamağın gerekli olduğu durumlar vardır. Bu kararı etkileyen faktörler; daha önceki cerrahi işlemler, çıkarmayı gerektiren tespitler, revizyonda kullanılacak tespit materyalleri, otolog kemik grefti ihtiyacı ve ameliyatın çeşitli kısımları için öngörülen sürelerdir. Teknik zorlukların öngörülmesi önemlidir. Maalesef, ideal şartlar altında ve en iyi planlama ile bile teknik sıkıntılar yaşanabilir. 
Uygun enstrümantasyon ve görüntüleme sistemleri altında bile, implant çıkarma gibi basit işlemler de dahi zorluk yaşanabilir. Bu da cerrahinin daha önemli aşamalarında kullanılacak kıymetli zamanın kaybına neden olur. Bu nedenle, ameliyatın ilk cerrahi basamağında tespitin çıkarılması ve debridman, yeniden dizilimin sağlanması, tespit gibi işlemlerin bir sonraki cerrahi basamakta yapılması daha iyi olabilir. Ek olarak, eğer intramedüller çiviler, büyük çaplı vidalar veya büyük çaplı diğer materyaller çıkarıldıysa, hastaya bu kemik kayıplarının doldurulması veya konsolide edilmesi için zaman sağlanmış olur. Bu süreçler, elektromanyetik alan ve ultrasonografik yöntemler gibi cerrahi dışı adjuvan tedavilerin kullanımı ile hızlandırılabilir. Amaç, tespitin etkinliğini arttırabilecek sonraki işlemlerde kullanılabilecek kemik kalitesini arttırmaktır.

Osteomiyelitten şüphelenilen durumlarda, basamaklı prosedürler önerilir. Ameliyat öncesi ileri görüntüleme osteomiyelitin teşhisinde yardımcı olsa da, kesin bir tanı ancak kemik kültürleri ve biyopsi ile olabilir. Enfeksiyon kemik iyileşmesini olumsuz etkilediğinden, osteomiyelit varsa, organizmaların tanımlanması ve uygun antibiyotiklerle tedavisi zorunludur. Birinci cerrahi seansta, osteomiyeliti ekarte etmek veya tedavi etmek için kemik biyopsisi ve kültürler uygulanır. Buna ek olarak, tespit materyalleri bu başlangıç cerrahi sırasında çıkarılır.

\section{DEFORMITE ANALIZi}

Deformite, her zaman ayak ve ayak bileğinin kaynamaması ile ilişkilidir. Uygulanan cerrahiler, kaynamama sorununa ek olarak, mevcut deformiteleri de gidermelidir. Deformite, ister ilk işlem sırasında yetersiz düzeltmeye bağlı olsun isterse kaynama yetersizliğine bağlı aşamalı gelişsin, düzeltilmelidir. Ana cerrahi amaçlardan biri, tam bir yeniden dizilimi sağlamaktır. Arda kalan herhangi bir deformite, strese veya kaynamama alanında düzensiz dağılmış aksiyel yüklenmeye neden olarak, revizyonun başarısızlık riskini arttırır. Arda kalan deformiteler, kompansatuvar yürüyüşlere neden olarak komşu eklemlerde dejeneratif süreçlere yatkınlığa yol açar. Bu nedenle, deformite değerlendirmeleri titizlikle ve kapsamlı yapılmalıdır. Değerlendirmeler, klinik muayene, radyografiler ve ileri görüntülemeyi içermelidir.

Klinik muayene, hem statik hem de dinamik değerlendirmeleri içermelidir. Frontal, transvers ve sagittal düzlem deformiteleri, hem açık hem de kapalı kinetik zincirler olarak değerlendirilmelidir. Kaynamama yeri ve çevresindeki eklemlerin açık kinetik zincir değerlendirmeleri önemlidir. Genellikle komşu eklemlerde kompansatuvar deformiteler gelişebilir. Evre III erişkin edinilmiş düztabanlık nedeniyle yapılmış artrodezi takiben, rezidüel valgus deformitesi ile birlikte subta$\operatorname{lar}(\mathrm{ST})$ eklemin uzun süren kaynamaması, ayak bileği valgusuna neden olabilir. Tam bir yeniden dizilimi elde etmek için ST kaynamamanın revizyon ameliyatı ile birlikte ayak bileği valgusu da düzeltilmelidir. Ayak bileği valgusunun fikse ya da esnek olup olmadığı tespit edilmelidir. Deformite pasif olarak düzeltilmeye çalışılmalıdır. Bu belirleme, açık kinetik zincir değerlendirmesi sırasında yapılabilir. Kapalı kinetik zincir veya yük verme sırasında değerlendirme de çok önemlidir. Deformite seviyesi ve kompansasyon alanları belirlenebilir. Hasta yük verme sırasında ayak ve ayak bileğini düzeltilmiş bir pozisyona getirebilmelidir. Bu gerçekleştirilemezse, o zaman deformite 'fikse' demektir. Hasta ayak bileği eklemini subtalar ekleme paralel konuma getiremiyorsa, eklem deformitesi fiskedir ve düzeltilmesi gerekir. Hasta düzeltilmiş pozisyona ulaşırsa, eklem deformitesi kaynamamanın yeniden diziliminin sağlanması ile tedavi edilebilir. Ayak bileğinin esnek valgus deformiteleri, deltoid bağ tamiri ve periartikül osteotomiler gibi eklem koruyucu prosedürlerle tedavi edilebilir. Bununla birlikte, fikse deformitede tam bir yeniden dizilim elde etmek için, ayak bileği artrodezi veya total ayak bileği protezi gerekir. Başka bir örnek de, valgus deformitesinde ayak bileği veya ardayak kaynamaması nedeniyle gelişen kompansatuvar ön ayak supinasyonu/varusudur. Kaynamama cerrahisi sırasında supinasyon/varusun düzeltilmesi gerekebilir. Bu deformiteler, ayak bileği veya ardayak dizilimi tekrar sağlandıktan sonra ortaya çıkabilir ya da artabilir. Fikse bir supinasyon/varus, ameliyat gerektirir. Ancak, esnek bir kaynamama, ayak bileği veya ardayak diziliminin tekrar sağlanmasıyla ek bir cerrahi gerekmeden çözülebilir. ${ }^{[28]}$

Düz radyografiler deformite değerlendirmesinin önemli bir parçasıdır, çünkü kaynamama ile ilişkili tüm diğer deformiteleri ortaya koyabilir. Uzunluk, açılanma, rotasyon ve translasyonu değerlendirmede radyografiler kullanılabilir. Karşı ekstremitenin yük verirken grafilerini elde etmek de önemlidir. Stres grafileri, ayak bileği kollateral bağlarının sağlamlığını değerlendirmede yararlı olabilir.

Kısalma kaynamamada nadir değildir. İşlevsel açıdan kabul edilebilecek kısalma oranı tespit edilmelidir. Kaynamama sahasında sağlıklı bir kansellöz doku elde etmek için gerekli kemik rezeksiyonunun tespiti önemlidir. Bu miktar, kullanılacak kemik greftinin türü ve boyutu üzerinde etkilidir. Dahası, bu miktar aynı zamanda gerekli tespit türünü ve komşu eklemlerin artrodez içine dahil edilip edilmeyeceğini de belirler. 
Açısal deformiteler, özellikle frontal ve sagittal plan$\mathrm{da}$, düz grafilerle iyice gözden geçirilebilir. ST veya ayak bileği eklemi artrodezi sonrası oluşan kaynamama, genellikle ciddi bir frontal düzlem deformitesi ile ilişkili olabilir. Deformitenin boyutunu düz grafiler gösterecektir. Bu sayede, kaynamama revizyon ameliyatı sırasında yeniden dizilimin sağlanması için gerekli planlar yapılabilir. Frontal düzlem deformitelerinde yeniden dizlimi planlarken şablonlar yardımcı olabilir. Tam bir yeniden dizilimin mümkün olup olmadığı, deformitenin büyüklüğüne bağlı olarak belirlenebilir. Ciddi bir deformitenin tam olarak düzeltilmesi, yara sorunlarına neden olabilecek yumuşak doku hasarlarına neden olabilir. Bu gibi durumlarda, eksik düzelme kabul edilmeli ya da kemik kısaltma düşünülmelidir. Aksi takdirde, olası yumuşak doku rekonstrüksiyonlarına hazır olunmalıdır.

Tarsometatarsal, orta ayak ve midtarsal eklem artrodezlerini takiben gelişen kaynamama, genellikle sagittal plan deformiteleri ile birliktedir. Aksiyel yükler her zaman dorsifleksiyon deformitelerine neden olur. Düz grafiler, deformitenin derecesini gösterip cerrahi planlamaya olanak sağlar.

Bu nedenle, kaynamama revizyon cerrahilerinde deformite düzeltilmesinin planlanmasında, düz grafiler çok önemlidir. Bu değerlendirmeler kapsamlı olmalı ve tüm uygun görüntüler elde edilmelidir. Grafiler, özellikle de ardayak ve ayak bileği tutulumu ile birlikte giden ciddi deformitelerin varlığında, tam yük vererek ve bilateral elde edilmelidir.

Gelişmiş görüntülemenin, kaynamamanın değerlendirilmesinde oldukça yararlı olabilirken, deformitenin değerlendirilmesinde kısıtlı kullanımı vardır. BT taramaları, transvers plan deformitelerin, özellikle rotasyonel ve translasyonel problemlerin değerlendirilmesinde yararlıdır. Bu deformitelerin klinik ve radyografik açıdan değerlendirilmesi zordur. Özellikle ST ve ayak bileği eklemini içine alan deformitelerde BT, deformitenin yönü ve büyüklüğü açısında önemli bilgiler verebilir.

\section{KAYNAMAMA REVIZYON CERRAHISINDE PRENSIPLER VE TEKNIKLER}

Neredeyse tüm durumlarda, kemikten aşağıya doğru tam kat kesiler kullanılmalıdır. Retraksiyonu kolaylaştırmak için, zarar vermekten kaçınılmalıdır veya en azından asgaride tutulmalıdır. Amaç, kesi alanındaki kan akışını kesintiye uğratmaktan kaçınmaktır. Ancak, özellikle sinirler ve tendonlar gibi önemli yapıların zarar görmemesi için anatomiye iyi hakim olunması gerekir. Ciddi realignment gerektiren zor deformitelerde, insizyonlar yumuşak doku kılıfının gerilim tarafının ters yönüne yerleştirilmelidir. Böyle bir yerleşim, orijinal kesiden uzak olan bölgelerde olabilir ki bu kesinlikle kabul edilebilir bir durumdur. Aksi takdirde, yumuşak doku kılıfının gerginlik tarafına yerleştirilen bir kesi, yara sorunlarına neden olabilir.

Yara dokusunun ayrıntılı bir şekilde disseksiyonu ve debridmanı önemlidir, çünkü kaynamamaya doğrudan erişimi sağlayacaktır. Ek olarak, eklem kontraktürüne neden olan skar dokusunun çıkarılmasıyla manipülasyona olanak sağlanır ve bu sayede dizilim tekrar sağlanabilir. Kaynamamış kısım belirlenmeli ve iyice debride edilmelidir. Tüm devitalize ve nekrotik doku tamamen çıkarılmalıdır. Debridmandan sonra, konak doku, fenestrasyon ve yüzeylerin kazınması ile hazırlanabilir. Keskin bir matkap ucu, sabit yıkama altında, vasküler kanallar oluşturmak için derin subkondral dokulara kadar ilerletilmelidir. Amaç, kanın kaynamama bölgesine girip, buraya hücreleri, kemik iliğini ve büyüme faktörlerini taşımasıdır. Fenestrasyonun ardından, küçük, keskin osteotomlar kullanılarak konak dokuda sağlıklı süngerimsi bir kemik tabaka oluşturulur. Bu prosedür agresif olarak yapılmalıdır, ancak yapısal bütünlüğü muhafaza etmek için kaynamamış bölgenin çevresindeki kortikal ve subkondral kemiğin korunmasına özen gösterilmelidir. Çevre dokulardaki bu yapısal kemik bütünlüğü, dizilimin tekrar sağlanmasını kolaylaştırmada ve rijid tespitin sağlanmasında önemlidir. Her ne kadar bu tür olguların çoğunda kemik greftleri veya kemik greft muadilleri kullanılsa da, yeterli kan tedariki olmadan kemik greftleri biyolojik aktiviteyi gösteremez. Bu nedenle, kaynamayı güçlendirmek için konak dokuların hazırlanmasında yeterli özen gösterilmelidir.

Tespitin birincil amacı, hareketi ortadan kaldıran stabil bir yapı sağlamaktır. İyileşme sırasındaki hareketler, kemik yüzeylerinin konsolidasyonunu ve kemiğin greftlerinin bütünleşmesini engeller. Bu olgularda sağlam bir cerrahi plana ihtiyaç duyulmasına rağmen, ameliyat sırasındaki bulgulara ve gelişmelere çözüm getiren alternatif tespit yöntemleri geliştirilebilmelidir. Alternatif tespit şekilleri planlanmalı ve bu cihazlar kullanıma hazır şekilde bulundurulmalıdır.

Tespit yönteminin seçimi, genellikle aşağıdaki faktörlerden etkilenir: osteopeni, kaynamamanın yeri, çevre eklemlere yakınlık, önceki tespit yöntemi, hasta uyumu, debridmandan sonra kemik kaybı miktarı, hastanın yük vermemeye toleransı, cerrahın yeterliliği ve endüstriyel/teknik destek. Şiddetli osteopeniyle veya kemik kaybıyla giden durumlarda, süper yapılar veya yakın eklemlerin fedası gerekebilir.

Teknolojideki son gelişmeler, tespit için pek çok mükemmel seçenek sağlamıştır. Vidalar mümkün olduğunca korteksleri veya kompakt subkondral kemiği tutmalıdır. Osteopenik veya kemik kalitesinin kötü 
olduğu olgularda, kilitli plak teknolojisi hastalar için mükemmel bir seçenektir. Alternatif olarak, kaynamama bölgesini nötralize eden ilave eksternal fiksatörler, aynı hasta popülasyonunda makul bir seçenektir.

\section{BIRINCI METATARSOFALANGEAL (MTF) EKLEMI}

Birinci MTF artrodezi sonrası kaynamama insidansı nispeten düşüktür. Halluks rigidusu takip eden son dönem artroz gelişen hastalar ile travma sonrası artrite sahip hastalarda görülme sıklığı, halluks valgus teşhisi konan hastalara göre daha yüksektir. Halluks rigidusa sekonder veya travma sonrası artrite bağlı gelişen son dönem artroz, sıklıkla daha kalın bir subkondral plaka ile ilişkilidir. Bu, sklerotik ve avasküler olabilir. Bu hastalar, bir halluks valguslu hastaya göre daha yüksek kaynamama eğilimine sahiptir. Bu nedenle, kan akışını arttırmak için, subkondral plakalara penetrasyon amacıyla eklem hazırlığı eksiksiz ve yeterli derecede olmalıdır. Eklem debridmanında kullanılan bazı reaming sistemleri yetersiz olabilir. Bu durumlarda, tek başına kullanılmamalı, drilleme teknikleri ile takviye edilmelidir.

Halluks rigidus nedeniyle distal metatarsal osteotomi uygulanan hastalar da avasküler nekroz (AVN) riski altındadır. AVN'yi değerlendirmek veya ekarte etmek için, ileri görüntüleme bu hasta grubunda yardımcı olabilir. Daha sonra, uygun debridman teknikleri ve artrodezi arttırmak için kemik greft veya ortobiyolojik madde kullanımı planlanabilir.

Halluksun plantar fleksiyonda konumlandırılması, yürüyüşün itiş safhasında ciddi aksiyel yüklenmeye neden olur. Bu hastalarda, özellikle de artrodez bölgesinde konsolidasyonun tamamlanmasından önce yük vermeye başlayanlarda, kaynamama gelişebilir. Birinci MTF artrodezin kaynamama oranının bu kadar düşük olmasının nedenlerinden biri, halluksun genellikle dorsifleksiyonda pozisyonlanması ve bu sayede yük verme sırasında artrodez bölgesine kuvvet uygulanmamasıdır.

Revizyon cerrahisi, kaynamamanın nedenlerine dayanmalıdır; etkileyen faktörlerden bağımsız olarak, kapsamlı debridman ve eklem hazırlığını, otojen kansellöz kemik ve/veya ortobiyolojik kullanımını, uygun pozisyonlama ve stabil tespiti içermelidir. Yapısal bir kemik grefti nadiren gereklidir ve bir miktar kısalma kabul edilebilir. Kalkaneus veya distal tibia metafizi, bölgesel otojen kansellöz kemik kaynaklarıdır. Birinci MTF kaynamama revizyonlarında, greft almak için 6 ya da $8 \mathrm{~mm}$ trefinler perkütanöz kullanılabilir. Tespit, uzun vidalar veya uzun plaklar kullanılarak artrodez sahasından uzaktaki kortikal kemiğe kadar uzanmalıdır. Kaynamamaya bağlı revizyon sonrasında altı hafta yük vermeme önerilir.

\section{TARSOMETATARSAL (TMT) EKLEM}

Birinci TMT artrodezi (modifiye Lapidus prosedürü), halluks valgus rekonstrüksiyonu için genel bir prosedürdür. Ek olarak, travmatik artrit ve deformite nedeniyle geniş çaplı TMT artrodez uygulanıyorsa, bu ekleme de sıklıkla artrodez uygulanır. TMT eklemler ve tüm orta ayak eklemlerindeki kaynamamalar, aksiyel yüklenmeye maruz kalındığında osseöz segmentlerin birbirine geçtiği, bir miktar makaslama bileşenine sahip vertikal yönelimli kaynamamalardır. Birinci TMT eklemin kaynamaması, genellikle aksiyel yüklenmeye bağlı birinci sıra elevasyonu ile ilişkilidir. Buna ek olarak, özellikle de uzun süreli olgularda, kısalık nadir değildir. Bu nedenle, revizyon hedefleri; kaynama, sagittal düzlemde dizilimin yeniden sağlanması ve uzunluğun restorasyonunu içermelidir. Belirgin kısalma varlığında, yapısal bir kemik grefti gerekli olabilir. Bununla birlikte, özellikle sagittal ve transvers dizilimin kolayca tekrar sağlandığı durumlarda, bu olguların çoğunda yapısal bir kemik greftine ihtiyaç duyulmamaktadır. Ölü kemik ve skar dokusunun debridmanı, sağlıklı bir konak ortamının gelişimi, otojen kansellöz kemik greftleri, ortobiyolojiklerin kullanımı ve stabil tespit, genellikle birinci TMT eklemin kaynamamasını çözmede yeterlidir. Kilitli plak teknolojisi bu durumda iyi bir seçenektir.

Küçük TMT eklemlerinin artrodezi (ikinci ve üçüncü) TMT eklem kompleksini içeren travma sonrası artrit veya deformite için gerekli olabilir. Küçük TMT eklemlerin kaynamaması, eklemlerin geniş çaplı artrodezi sonrasında gelişebilir (1.-3. eklem). Neyse ki, küçük TMT eklem artrodezini takip eden kaynamama, nadiren dizilim bozukluğu ile ilişkilidir. Revizyon tipik olarak kapsamlı debridman, konak dokunun hazırlaması, kemik greftleme/ortobiyolojiklerin kullanımı ve stabil tespiti içerir.

\section{TRITARSAL KOMPLEKS}

İzole, seçilmiş veya üçlü artrodez sonrası kaynamama nadir değildir. Revizyon ameliyatı, sadece kaynamamayı değil, aynı zamanda diğer ilgili sorunları da çözmelidir. Bunlar arasında; yetersiz düzeltme, yanlış kaynama, ayak bileği valgusu veya varusuna bağlı kollateral bağ zayıflaması, başlangıçta ilk cerrahi sırasında tanımlanamamış mediyal kolon instabilitesi, ilk cerrahi sırasında yeterli oranda gevşetilmemiş yumuşak doku kontraktürleri ve tanımlanmamış daha proksimal sorunlar sayılabilir. Revizyon ameliyatının hedefleri; kaynama, plantigrad bir ayağın restorasyonu ve işlevin korunmasıdır. Ameliyat öncesi hazırlıklar; dizilimi değerlendirmek için özel grafileri, uygun ileri görüntüleme yöntemlerini ve hastanın en uygun seviyeye 
getirilmesini içerir. Ameliyat sırasındaki hedefler, kaynamama alanında sağlıklı bir süngerimsi alt tabaka sağlamak ve dizilim tekrar sağlamaktır. Bunların başarılmasında; özelleşmiş teknoloji, uygun enstrümantasyon, kemik greftleri, ortobiyolojikler ve görüntüleme yöntemleri yardımcı olur. Kaynamamanın düzeltilmesine ek olarak, osteotomiler, yumuşak doku kontraktürlerinin serbestleştirilmesi, gerektiğinde diğer eklemleri içeren genişletilmiş artrodez uygulanmalıdır.

ST eklemin izole artrodezi sonrası kaynamama, cerrahi olarak ST artrodezin izole revizyonu ile veya üçlü artrodeze dönüşüm ile tedavi edilebilir. ST artrodez sonrası en yüksek kaynamama oranı, kalkaneal kırık sonrası posttravmatik artritte görülür. Eğer dizilim bozukluğu yoksa ve talonaviküler (TN) ve kalkaneoküboid (CC) eklemde dejenerasyon mevcut değilse, ST kaynamamanın izole revizyonu tercih edilmelidir. Bu karar çoğunlukla, klinik değerlendirmeye ve preoperatif görüntülemeye dayanmaktadır. Tespit metodu tipik olarak büyük çaplı kompresyon vidalarıdır. Korteks veya subkondral alanları bağlayan birden fazla vida kullanı$\mathrm{m}$ tercih edilir. Ancak, dizilim bozukluğu ya da tespiti olumsuz etkileyecek etmenler mevcutsa, ST kaynamama üçlü artrodeze dönüştürülür. Bu prosedür, tespit sonrasında tüm tritarsal kompleksin rijiditesini arttırır ve tespit için birden fazla seçenek sunar.

TN artrodez sonrası kaynamama oranı nispeten yüksek olarak bildirilmiştir. ${ }^{[29,30]}$ Dizilim iyi olsa bile izole revizyonu zordur. Genelde öneriler üçlü artrodeze dönmektir. CC artrodez, TN eklemdeki kompresyonu arttırır ve deformasyon olduğu zaman daha kolay yeniden dizilime olanak sağlar. Buna ek olarak, ST eklemin de füzyon kütlesine katılması ile, tüm yapıya daha fazla rijidite eklenir. Tüm tritarsal hareketin tamamen ortadan kaldırılması, TN eklem revizyon cerrahisi sırasında kaynama olasılığını arttırır. Talonaviküler eklemin tespiti tipik olarak lateral kompresyon vidalarını ve mediyal bir kilitli plağı içerir. Bununla birlikte, artrodez alanında eşit kompresyon sağlamak için çoklu kompresyon vidaları da eklenebilir.

Evre III ya da IV erişkin edinilmiş düztabanlıkta, selektif artrodez yaygın bir işlem haline gelmiştir. Her ne kadar kaynamama sıklığı bildirilmemişse de genel kanı, özellikle TN eklemde, üçlü artrodez ile karşılaştırıldığında daha yüksek bir oranda olduğudur. ${ }^{[31]}$ Tercih edilen yöntem, ST ya da TN eklemdeki kaynamamanın üçlü artrodezlere çevrilmesidir.

Üçlü artrodezi takiben, tritarsal eklemlerin herhangi birinin veya tümünün kaynamaması mümkündür. Kaynamamanın tedavi prensipleri aynıdır. Debridman, eklemi hazırlama, dizilimin yeniden sağlanması, kemik greft/ortobiyolojik ve gelişmiş tespit gereklidir. Ciddi osteopeni veya erken yük vermeyle ilgili endişeler varsa, internal tespite ek olarak eksternal tespit uygulanabilir.

\section{AMELIYAT SONRASI BAKIM}

Biyolojik cevaplar yük ve stabiliteden etkilenir. Revizyonal kaynamama cerrahileri her zaman uzun süreli hareketsiz kalma ve ağırlık vermeme dönemleri gerektirir. Özellikle, hasta ameliyat öncesinde bile yapamıyorsa, yük vermemeye yönelik fizik tedavi konsültasyonu önerilir. Bu hastalarda, dizden destekli yürüteçler, tekerlekli sandalyeler vb. yararlı olabilir. Derin ven trombozu profilaksisi önerilir ve risk faktörleri tarafından belirlenir. Cerrahiyi takiben iyileşmeyi desteklemek için elektrik stimülasyonu veya ultrasonografi kullanı$\mathrm{m}$ önerilir. Kaynama takibi, seri radyografiler ve ileri görüntüleme ile yapılmalıdır. Yük vermeye başlamadan önce BT ile konsolidasyonun doğrulanması önerilir.

\section{ÇIKARIMLAR}

Cerrahi kaynamama, ayak ve ayak bileği cerrahları tarafından yüzleşilen karmaşık bir durumdur. Kaynamamaların başarıyla yönetimi; kemik iyileşmesinin anlaşılmasını, kemik metabolizması anormalliklerine katkıda bulunan tıbbi durumların farkında olunmasını, hastalarda kaynamamaya neden olan teknik konular hakkında bilgi sahibi olmayı ve tespit ilkelerini anlamayı gerektirir. Çoğu olguda başarılı sonuçlar elde etmek için multidisipliner takım yaklaşımı önerilir.

\section{KAYNAKLAR}

1. Riemer BL, DiChristina DG, Cooper A, Sagiv S, Butterfield SL, Burke CJ 3rd, Lucke JF, Schlosser JD. Nonreamed nailing of tibial diaphyseal fractures in blunt polytrauma patients. J Orthop Trauma 1995;9(1):66-75.

2. Caudle RJ, Stern PJ. Severe open fractures of the tibia. J Bone Joint Surg Am 1987;69(6):801-7.

3. Sanders R, Jersinovich I, Anglen J, DiPasquale T, Herscovici D Jr. The treatment of open tibial shaft fractures using an interlocked intramedullary nail without reaming. J Orthop Trauma 1994;8(6):504-10.

4. Govender S, Csimma C, Genant HK, Valentin-Opran A, Amit $\mathrm{Y}$, Arbel R, Aro H, Atar D, Bishay M, Börner MG, Chiron $\mathrm{P}$, Choong P, Cinats J, Courtenay B, Feibel R, Geulette B, Gravel C, Haas N, Raschke M, Hammacher E, van der Velde D, Hardy P, Holt M, Josten C, Ketterl RL, Lindeque B, Lob G, Mathevon H, McCoy G, Marsh D, Miller R, Munting E, Oevre S, Nordsletten L, Patel A, Pohl A, Rennie W, Reynders P, Rommens PM, Rondia J, Rossouw WC, Daneel PJ, Ruff S, Rüter A, Santavirta S, Schildhauer TA, Gekle C, Schnettler R, Segal D, Seiler H, Snowdowne RB, Stapert J, Taglang G, Verdonk R, Vogels L, Weckbach A, Wentzensen A, Wisniewski T; BMP-2 Evaluation in Surgery for Tibial Trauma (BESTT) Study Group. Recombinant human bone morphogenetic protein-2 for treatment of open tibial fractures: a prospective, controlled, randomized study of four hundred and fifty patients. J Bone Joint Surg Am 2002;84-A(12):2123-34. 
5. Sangeorzan BJ, Smith D, Veith R, Hansen ST Jr. Triple arthrodesis using internal fixation in treatment of adult foot disorders. Clin Orthop Relat Res 1993;(294):299-307.

6. Wukich DK, Bowen JR. A long-term study of triple arthrodesis for correction of pes cavovarus in Charcot-Marie-Tooth disease. J Pediatr Orthop 1989;9(4):433-7.

7. Saltzman CL, Fehrle MJ, Cooper RR, Spencer EC, Ponseti IV. Triple arthrodesis: twenty-five and forty-four-year average follow-up of the same patients. J Bone Joint Surg Am 1999;81(10):1391-402.

8. Maskill MP, Loveland JD, Mendicino RW, Saltrick K, Catanzariti AR. Triple arthrodesis for the adult acquired flatfoot deformity. Clin Podiatr Med Surg 2007;24(4):76578. Crossref

9. Goucher NR, Coughlin MJ. Hallux metatarsophalangeal joint arthrodesis using dome-shaped reamers and dorsal plate fixation: a prospective study. Foot Ankle Int 2006;27(11):86976. Crossref

10. Doty J, Coughlin M, Hirose C, Kemp T. Hallux metatarsophalangeal joint arthrodesis with a hybrid locking plate and a plantar neutralization screw: a prospective study. Foot Ankle Int 2013;34(11):1535-40. Crossref

11. Roukis TS. Nonunion after arthrodesis of the first metatarsalphalangeal joint: a systematic review. J Foot Ankle Surg 2011;50(6):710-3. Crossref

12. Catanzariti AR, Mendicino RW, Lee MS, Gallina MR. The modified Lapidus arthrodesis: a retrospective analysis. J Foot Ankle Surg 1999;38(5):322-32.

13. Donnenwerth MP, Borkosky SL, Abicht BP, Plovanich EJ, Roukis TS. Rate of nonunion after first metatarsalcuneiform arthrodesis using joint curettage and two crossed compression screw fixation: a systematic review. J Foot Ankle Surg 2011;50(6):707-9. Crossref

14. Thompson IM, Bohay DR, Anderson JG. Fusion rate of first tarsometatarsal arthrodesis in the modified Lapidus procedure and flatfoot reconstruction. Foot Ankle Int 2005;26(9):698-703. Crossref

15. Goldman B. Use and abuse of opioid analgesics in chronic pain. Can Fam Physician 1993;39:571-6.

16. Savage SR. Opioid use in the management of chronic pain. Med Clin North Am 1999;83(3):761-86.
17. Tennant FS Jr, Rawson RA. Outpatient treatment of prescription opioid dependence: comparison of two methods. Arch Intern Med 1982;142(10):1845-7.

18. Day SM, DeHeer DH. Reversal of the detrimental effects of chronic protein malnutrition on long bone fracture healing. J Orthop Trauma 2001;15(1):47-53.

19. Einhorn TA, Levine B, Michel P. Nutrition and bone. Orthop Clin North Am 1990;21(1):43-50.

20. Guarniero R, de Barros Filho TE, Tannuri U, Rodrigues CJ, Rossi JD. Study of fracture healing in protein malnutrition. Rev Paul Med 1992;110(2):63-8.

21. Pollak D, Floman $Y$, Simkin A, Avinezer A, Freund HR. The effect of protein malnutrition and nutritional support on the mechanical properties of fracture healing in the injured rat. JPEN J Parenter Enteral Nutr 1986;10(6):564-7. Crossref

22. Hoofwerf BJ, Sferra J, Donley BG. Diabetes mellitus-overview. Foot Ankle Clin 2006;11(4):703-15. Crossref

23. Brinker MR, O'Conner DP, Monla YT, Earthman TP. Metabolic and endocrine abnormalities in patients with nonunions. J Orthop Trauma 2007;21(8):557-70. Crossref

24. Dworkin SF, Von Korff M, LeResche L. Multiple pains and psychiatric distrurbance. An epidemiologic investigation. Arch Gen Psychiatry 1990;47(3):239-44.

25. Katon $\mathrm{W}$. The impact of major depression on chronic medical illness. Gen Hosp Psychiatry 1996;18(4):215-9.

26. Katon W, Sullivan MD. Depression and chronic medical illness. J Clin Psychiatry 1990;51 Suppl:3-11.

27. Krishan KR, France RD. Chronic pain and depression. South Med J 1987;80(5):558-61.

28. Evans EL, Catanzariti AR. Forefoot supinatus. Clin Podiatr Med Surg 2014;31(3):405-13. Crossref

29. Mann RA, Beaman DN. Double arthrodesis in the adult. Clin Orthop Relat Res 1999;(365):74-80.

30. Granata JD, Berlet GC, Ghotge R, Li Y, Kelly B, DiAngelo D. Talonavicular joint fixation: a biomechanical comparison of locking compression plates and lag screws. Foot Ankle Spec 2014;7(1):20-31. Crossref

31. Catanzariti AR, Adeleke AT. Double arthrodesis through a medial approach for end-stage adult-acquired flatfoot. Clin Podiatr Med Surg 2014;31(3):435-44. Crossref 